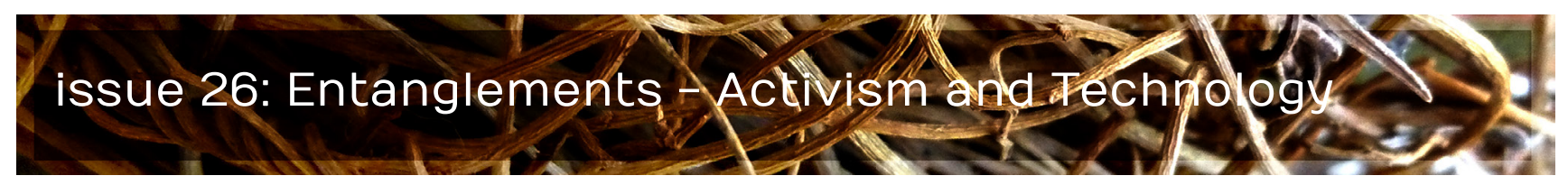

\title{
FCJ-188 Disability's Digital Frictions: Activism, Technology, and Politics
}

Katie Ellis

Curtin University

Gerard Goggin

University of Sydney

Mike Kent

Curtin University

\begin{abstract}
:
This paper argues that disability activism and politics can be seen as paradigmatic for the wider debates on the philosophies, forms, and formats embedded in technologies. Firstly, the paper discusses disability activism movements that use digital technology to intervene into digital technology, especially in the social media area. In both cases, activists seek to use the platforms themselves to argue for, and obtain, greater accessibility, customisability, and configurability, of the platform for users with disabilities. Yet there is a clear clash between philosophies embedded within these social media platforms, and the aspirations and values of many of the activist strands of disability. Secondly, the paper explores the use of digital technologies by disability activism movements in relation to welfare and work reforms-notably the UK struggles in the 2010-2014 periods. Here disability activists have made extensive use of digital media technologies, and we discuss their innovations, and the lessons they offer.
\end{abstract}

doi: 10.15307/fcj.26.188.2015 


\section{Introduction}

Increasingly, disability is acknowledged as a key part of society, public and private spheres, and everyday life. Moreover, disability has achieved notable recognition and endorsement as an area of inequality, oppression, and discrimination that requires concerted global and local action.

We see various markers of this transformation in the social relations of disability. In the legal realm there is the enactment of the United Nations Conventions on the Rights of Persons with Disabilities (Arnardóttir and Quinn, 2009; Flynn, 2011), and the cumulative effect of many important laws and regulations enacted by governments around the world (Francis and Silver, 2000; Waddington, Quinn and Flynn, 2015). Related positive developments include greater visibility and potency of people with disabilities in public spheres and counter public spheres.

There is increasing acknowledgement of the specific gender, class, race, and sexuality dimensions of disability (Kulick and Rydström, 2015; McCruer, 2006; Samuels, 2014). Also notable is the dawning mainstream recognition for efforts to understand and transform the situation of indigenous people with disabilities (Soldatic, Spurway and Meekosha, 2014). Finally overdue attention is being paid to disability in the majority world, often termed the 'global south', or 'developing world' (Grech and Soldatic, 2015; Soldatic and Meekosha, 2014). Questions of survival and the precarity of existence are raised starkly in these countries, for people with disabilities especially those belonging to the less wealthy or powerful groups-those many people who are among the most marginalised and excluded (Erevelles, 2011).

Much oppression and many challenges remain concerning disability justice. There is a precariousness of living with a disability in contemporary Western societies. While there have been significant initiatives on work and labour issues (Bruyère and Barrington, 2012; Heymann, Stein and Moreno, 2014), the realities and stereotypes of disability are clearly visible in debates on welfare policy, work, and disability support (Lindsay and Houston, 2013; Marin, Prinz and Queisser, 2004; Roulstone, 2012; Soldatic, Morgan and Roulstone, 2014).

These are some of the important contexts for the groundswell of activism in relation to disability. Such activism, and indeed the contours of disability in everyday life, has intimate 
and consequential connections with technology. Digital technology provides new kinds of tools, support, and power for people with disability. Thus digital technology is often vital for everyday life, but also for engagement and participation in contemporary politics, culture, and media (Blume, 2012; Mills, 2011). A specific kind of activism has emerged here that focusses on the shortcomings, problems, and inaccessibility of digital technology for many people with disabilities (Blanck, 2015; Ellis and Kent, 2011; Goggin, 2014; Goggin and Newell, 2003; see also Padovani \& Calabrese, 2014). However, there is a much broader perspective needed here. To start with, it is important to note that disability has very interesting relationships with technology (Hickey-Moody and Wood, 2008; Moser, 2005), something that makes sense if we acknowledge the social nature of disability (Goggin and Newell, 2003; Roulstone, 1998). Various modern social imaginaries as well as materialities of disability involve technology (Goggin and Noonan, 2006), just as much as they are premised on activist and transformative accounts of disability movements. Disability and technology can be seen as entangled (Thomas, 1991), whereas they are often regarded as quite separate-for instance, in discourses of web accessibility (Adam and Kreps, 2009), or in assistive technology. There is a growing situation of interdependence for many people with disabilities-as in social life generally-whereby life without some kind of technology seems unachievable and unimaginable (Goggin and Newell, 2006).

The kinds of digital technology we discuss here are eminently global in their nature, providing the international connections that undergird and make possible the social transformations of disability-as well as the universal claims, for instance, of human rights. While discourses of globalisation and technology in the 1990s in particular saw motion and global connection as increasingly trouble-free and friction-less, the reality is a contradictory, messy, materially situated process (Tsing, 2005: 5-6). Rather than there being a binary, for instance, between 'access' and 'non-access', we see friction in operation across the global field of disability and technology-especially in relation to disability activism.

Accordingly, in this paper we use this disability analysis and theorisation to reflect back upon the general problematics of how technology and activism are sutured together. The two main case studies of the paper proceed to explore these two tightly connected aspects of disability activism and technology.

In the first part of the paper, we take up the long-running struggle of disability activists over accessibility of digital technology. We start with highly publicised movements around the accessibility of Facebook and Twitter. In both cases, activists seek to use the platforms themselves to argue for, and obtain, greater accessibility, customisability, and configurability, of the platform for users with disabilities. Yet there is a clear clash between 
philosophies embedded within these social media platforms, and the aspirations and values of many-stranded disability activism.

The second part explores the use of digital technologies by disability activism movements in relation to welfare and work reforms. We look particularly at the British disability movement's struggles around welfare reforms since the election of the Conservative government in 2010 and the 2012 Paralympic Games, where disability activists have made extensive use of digital media technologies. A fascinating instance is also found in the work of artist Liz Crow, who has used social media to facilitate conversation and debate around her installation work that exposes and critiques disturbing and oppressive aspects of the UK disability welfare forms.

\section{Disability Activism Confronts Technology: Beyond Accessibility}

As we have discussed, disability activism is a fascinating and important case of creating and realising the 'democratic affordances' of digital technologies (Goggin, 2013). For the most part, such technology-enabled disability activism has not been chronicled, theorised, or debated in the burgeoning literatures on social movements, social media and other digital technologies, and activism. Acknowledgement, incorporation, and exploration of disability activism's contribution to the ideas, practices, and repertoire of digital activism more generally is a project well underway in the social movements themselves-but scarcely commenced in research and scholarship.

This disability technology activism has involved a range of actors-activists with disability, allies, technology experts and developers (with and without disability), civil society organisations, governments, and human rights practitioners. Effectively such activism has identified, debated, and challenged the philosophies in digital technologies for many years-especially in the period of the Internet's widespread diffusion from the 1990s onwards. Following the lead of Judy Wajcman in her classic 1991 book on the politics of technology, Feminism Confronts Technology we could easily dub this movement 'disability confronts technology' (Wajcman, 1991).

Broadly speaking, this movement is better known as focused on Internet accessibility for people with disabilities. It is best developed and most widely familiar in the area of the World Wide Web, due to the efforts of the World Wide Web Consortium (W3C) Web Accessibility Initiative (WAI) (Brewer, 2001). The W3C WAI commenced in 1997. Famously Sir 
Tim Berners-Lee called for the web to be globally accessible-a universal medium. This is a call he has renewed in the commemoration celebrations in 2014, suggesting the Internet is at a crossroads. Berners-Lee sees accessibility of the Internet for people with disabilities as a core part of realising his broader vision for the universal accessibility of the Web and Internet, and now mobile and other associated technologies. The W3C WAI, and the wider movement centering on the accessibility of digital technology seek to contest a particular philosophy of technology, especially around invention, design, and creativity.

Namely, that technology designers should be free to write the code, design, construct, and implement the technology they wish. For their part, users can choose to adapt and fit their desires to the platform, or, alternatively, seek another platform. The accessibility movement counterposes a different philosophy of technology, with a core argument that accessibility should always be part of the innovation and design process of digital technology.

Perhaps the most influential strand of this counter-philosophy is 'universal design', the idea that technology should, as far as possible, be designed for the widest population possible (Preiser and Ostroff, 2001). If one designs for disabled users, the argument goes, then the end result will be technology that is of more use (and more accessible) to a wider range of users.

A concrete example may be found in contemporary multimedia, which is often not accessible for particular groups, or individuals. To address this, sub-titling online videos for Deaf people or hard-of-hearing users, for instance, means that users in noisy environments, or who need to mute their device volume, or for videos where users find the language hard to understand can be assisted also. It also allows users to search within videos.

Universal design has been adopted in mainstream documents and practices, including the UN CRPD. It is important to note that universal design, especially in its simple forms, poses its own problems for disability activism and broader concepts of disability (see Goggin and Newell, 2003; and Imrie and Luck, 2014). There is a tension, for instance, between the universalising impulse-and the need to understand, address, and support the oftencontradictory needs and expectations of situated, specific groups and individuals.

In many ways, the ideas of digital accessibility have their roots not just in confronting discrimination and exclusion, but also in philosophies of user-centred design, across a range of disciplines and settings, including the Human-Computer Interaction ( $\mathrm{HCl})$ field. 
A cognate idea is the longstanding ideal of participatory design: the claim-in weaker or stronger versions-that users, and others affected by technological systems, should have some stake and say, some genuine control, in their design and implementation (Schuler and Namioka, 1993).

Web accessibility has focussed on large organisations, commercial, NGOs, and governments and their agencies. It has relied upon governments to enact laws that require web accessibility. Governments have also been viewed as important leaders in accessibility - with a duty, for instance, to ensure that government departments and agencies are good role models in making their websites, and services, accessible to all citizens and users, especially those with disabilities.

Suffice to say, the progress of web accessibility-even in its most basic requirements-has been slow. Some critics of web accessibility have made fundamental critiques also, arguing that its framing, discourses, and actors continue to perpetuate a narrow, oppressive view of disability (see Lewthwaite, 2014; for a critique of disability access in general, see Titchkovsky, 2011).

In particular, a tension exists between the socio-political use of social media as a platform for activism and 'the commercial interests of the platform owners' (Youmans and York, 2012). This is something that has been widely acknowledged and discussed elsewhere, in critiques from different perspectives (such as Andrejevic, 2007; and Fuchs, 2014a \& 2014b). For instance, Facebook is recognised as a potential site of empowerment and social inclusion for people with disability as widely discussed across disability culture and activism, and recognised in some literature (see Haller, 2010; Hollier, 2012). Yet the platform itself has a vexed relationship with accessibility (Ellis and Goggin, 2015).

For instance, in 2007, Andrew McKay, a student with vision impairment prompted an American Foundation of the Blind accessibility overhaul of Facebook following his activism, via the Facebook page The Official Petition For a More Accessible Facebook (Ellis and Goggin, 2015; Ellis and Kent, 2011; Haller, 2010). The page attracted over 1500 members and urged Facebook to correct seven accessibility errors. While Facebook did pay attention and implemented accessibility changes in consultation with the American Foundation of the Blind subsequent updates have again compromised access for users with vision impairment (Holler, 2012). 
Similar accessibility issues have been identified with the Twitter platform where users with vision impairments have experienced difficulties accessing the text based medium with screen readers (Ellis and Goggin, 2014; Ellis and Kent, 2010). When Twitter initially ignored the issue, independent web developers created accessible Twitter third party apps such as Dennis Lembree's 'Accessible Twitter' (later renamed EasyChirp). However, Twitter has since announced ongoing accessibility improvements to the Twitter app (Twitter, 2013; Twitter, 2014).

At a deep level, online access to a text is linked to power and control. Simply put, Facebook does not want to refer its users to other sites, it wants them to stay within the Facebook ecosystem for monitoring and advertising, thus it will embed videos from other sites within its own news stream rather than refer users away to another site. Google adopts a similar model. However these practices come with certain assumptions about what is 'normal' in the users of these services. While the Internet has provided an avenue of increased access to information and activism, there are still barriers, often unintended, that prevent people with disabilities from accessing this material. An urgent area for improvement is routine provision of video captioning and audio description of material to provide modalities for access.

A number of disability theorists highlight a paradox between the potential for increased social participation via the Internet for people with disability and the continuing isolation they experience as a result of inaccessible platforms and interfaces. For example, Sourbati argues that as communications are moving to an all-digital environment, public policy needs to be rethought (Sourbati, 2012: 571). She describes access to ICTs and the services provided by them as critically important arguing that that not having access to these "can be seen to prevent individuals from fulfilling active roles in society' (575). We can sharpen up the edges of this discussion, when we consider activism and political participation. If applications, interfaces, devices-in short, affordances of digital technology-are not accessible, open, and configurable, when activism often requires such technology, then there is a clear problem.

Disability activism concerning technology, then, has strong links with broader debates about rights to technology, such as the renewed movement focused on 'Internet rights', and 'Internet freedom', which recognises that democracy is entangled with technologyand that people's capacity to avail themselves of technology is foundational. If the platforms are not supportive of such aspirations, not only is it difficult for 'communicative capitalism' to function (Dean, 2009), but any emancipatory or transformative political project is stymied. 


\section{UK Welfare Reform Protests: Disability Activism with Digital Technology}

There are a number of striking contemporary cases of people with disabilities and how their allies use digital technology to organise protests aimed at improving and transforming their lives-and to broadly engage in political, cultural, and social participation.

In broadly similar ways to those canvassed in the online activism literature (Boler, 2008; Dahlgren, 2013; Lievrouw, 2011; Meikle, 2002; Ratto and Boler, 2014), digital technology is being widely used to organise physical protests to raise awareness of disability rights issues. Such technology is relied upon during protests for organisation and co-ordination. Increasingly also through social media, digital technology serves as a way of publicising the protest action. It is both a substitute for mainstream media and a way of better connecting to, and drawing the attention of, mainstream media. Digital technology offers a way for those are unable to participate or be co-present in the designated places or sites of protest to still be involved. Finally, there is the still evolving area of 'purely' online activism-that is, activism largely based, or decisively, based online-what Zizi Papacharissi calls the 'agonistic pluralism of online activism' (Papacharissi, 2010: 157ff).

So far, so good. However, as we have already signalled in our preceding discussion of the accessibility and disability struggles over technology (under the watchword of 'disability confronts technology'), there are significant contradictions at play here. As we have argued thus far, this kind of friction between disability and the dispositions of technologies is not just a blockage or problem; rather it is a rich source of social action, ideas, and reflections that opens up into the larger problematic of political beings, participation, justice, and technologies, framing these against a broader horizon.

To unpack this, it is first important to say that while attention is often accorded to disability protest associated with digital technology, disability activism has long genealogies and debates (Chouinard, 1999; Fleischer and Zames, 2011; Newell, 2006; Oliver and Barnes, 2012; Sandell, Dodd, and Garland-Thomson, 2010; Shapiro, 1993). It is a big area, still requiring histories, research, and debate, but let us indicate some significant moments and tendencies in disability activism. Originally drawing inspirations from dissent and resistance, such as struggles of the women's suffragists before the First World War, or the protest movements of the 1960s (Shakespeare, 1993), disability rights protests were highly visible in the 1970s-for example in New York over accessible public transport, and over regulations around Section 504 of the Rehabilitation Act (Harris, Owen and De Ruiter, 2012). The relationship of disability activism to larger histories is highlighted in the often 
remarked story of wheelchair users in New York receiving help from the revolutionary group Weather Underground to dynamite kerbs that were not modified for wheelchair access (Pelka, 2012: 445, 593; Shakespeare, 1993). New kinds of disability activism have emerged around new categories and concepts, not least cognitive impairments, mental health and psychiatric disabilities, episodic and chronic conditions, and responses to genetics and biopower (Hughes, 2009; Kelly, 2013; Snyder and Mitchell, 2001; Scotch, 1988; Shakespeare, 2015).

These kind of larger frameworks for disability activism and protest movements help us to situate the way that, in recent times, digital media has been deployed to great effect. Digitally-enabled and inflected protest is a global phenomenon, of which little research exists (an exception being the research of Trevison 2013, 2014, and 2015). To explore the forms such technology interdependent citizenship takes, here we will focus on the UK protests that arose in response to the cuts made to disability benefits by the conservative government, particularly, leading up to, and during, the 2012 Paralympic games in London. As leading disability activist and artist Liz Crow nicely put it:

Timing a season of protest to coincide with the height of the Paralympics and benefits coverage, they sought to draw maximum press coverage of their campaign for justice and human rights for all disabled people in a time of austerity and welfare cuts ... In doing so, they showed what they were made of (Crow, 2014: 179).

These protests brought the use of digital communications technology to the fore, specifically to enable and support this political expression by people with disabilities in the face of severe cuts to disability support programs being made by the Cameron conservative government.

Leading up to the London Olympics were the National Day of Action protest on 24 January 2011 and the larger Hardest Hit protest of 11 May 2011. Both events had a well-documented online presence that was used to promote the events beforehand, and help mobilise and organise the protests (Preston, 2011). The first protest challenged a key aspect of the UK welfare reforms - the changes in how people with disabilities were assessed by the government as either 'fit for work' or 'unfit' and eligible for government welfare assistance. The protestors targeted Atos Origin, the company contracted to carry out the 'fit for work' assessments as part of administering the government's changes to disability payments. Atos present themselves as follows: 
We work closely with government to support its welfare reform agenda: 'helping people move into and progress in work, while supporting the most vulnerable' (Atos, 2015).

This is not a view shared by the disability activists opposing the reforms, criticising the pivotal role Atos played-and how the company acted. Atos Origin was also a sponsor of the Paralympics and the company would be a focus of protest again as the Paralympics ran the following year (Morse, 2012). The Hardest Hit protests' ability to mobilise and organise online drew between 3000 and 8000 protesters and brought together 200 separate disability rights organisations (Preston, 2011).

There are a number of platforms that help both organisers and participants in protest actions during protests. The use of mobile media to mobilise demonstrations was famously pioneered as part of the popular protests that saw President Estrada ousted from power in the Philippines in 2001 (Coronel, 2001; Pertierra et al., 2005). Since then the advent of smart phones and social media has greatly facilitated communications in these contexts, from the use of Twitter on mobiles, to more dedicated platforms such as the Sukey app that assists protesters avoid being 'kettled' (confined to small area during protest) by police in London (Geere 2010), or by mobile phone operated drones used by protesters to follow police activity (Ackerman, 2011).

While people with disabilities make use of these different affordances while marshalling and participating in protests, these platforms can also be used to both interact with, and circumvent, the mainstream media. So, for instance, in January 2012 in an action organised by Disabled People Against Cuts, a number of protesters in wheelchairs chained themselves together across Oxford Circus in London, bringing traffic to a halt for a number of hours. In this protest there was a heavy use of social media by people involved in the protest and the event was well documented on YouTube. This protest action reprised a famous previous protest. In 1990 CAT (Campaign for Accessible Transport) had previously blocked Oxford Street with a similar line of people in wheelchairs chained together. In 1990, the police had trouble dealing with wheelchair users while making arrests. Add to which, proceedings against many of the protesters were dropped when the courthouse where they were to be heard proved inaccessible (Shakespeare, 1993). This was grist to the mill for the protestors, as Allan Sutherland, press officer for CAT, remarked at the time: 'CAT was effective because its demos were well-organised, its message was simple, it provided good photo opportunities for the media and it had public support' (quoted in: Peck, 2010). Similar problems for police in dealing with people with disabilities were evident more recently in Australian protests when police were ill-equipped to arrest wheelchair users protesting cuts to disability coverage by the $A B C$ (Morton and Baxendale, 
2014). This had been an issue previously in the well-documented case of Jody Mclntyre being knocked from his wheelchair by police in the UK 2010 student fees demonstrations (Taylor, 2010).

Unlike the CAT protest, the prospect of media friendly images did not draw much attention to the 2012 Disabled People Against Cuts protest. However, the availability of YouTube videos through social media was used by the mainstream media, particularly The Guardian newspaper, to report the story. Similarly the police assault on Jody McIntyre became mainstream news after traditional media sources picked up video posted to YouTube through social media.

While people in wheelchairs may present a challenge for the police, actually attending physical protests also presents challenges for people with disabilities. There are a number of impediments including the costs of travel, and practical logistics of attending an event for a prolonged period of time including working with carers, toileting, and physical exhaustion, and in the case of these protests in the United Kingdom, the fear of being seen at the protest by people from the Department of Works and Pensions and then be declared 'fit for work' and the subsequent loss of benefits (Gentleman, 2011). Butler (2012) notes concerns that traditional methods of disability activism appear to be diminishing but that social media activism is on the rise, and makes the specific suggestion that this rise can be attributed to the UK government's welfare reforms.

Coinciding with the vote on welfare reform in the UK, Twitter, in particular, became an increasingly important forum for disability activists from early January of 2012 (Ryan, 2014). A number of disability activists used the platform to report on the hidden opposition to the government's plans to reform disability benefits. A coalition of 'sick and disabled people, who came together through social media' released the Responsible Reform report online and promoted it through Twitter. The report which became known online as the Spartacus report was 'entirely researched, written, funded and supported by disabled people' with information obtained through Freedom of Information requests. Campbell (2012) detailed that during the government's consultation period:

- 98 per cent of respondents objected to the qualifying period for benefits being raised from 3 months to 6 months.

- 99 per cent of respondents objected to Disability Living Allowance no longer being used as a qualification for other benefits. 
- 92 per cent opposed removing the lowest rate of support for disabled people (Campbell et al., 2012).

The activists argued that this information was kept from both the public and MPs debating the issue. Three months prior to the release of this report and associated social media attention, physical protests across the United Kingdom were called to protest against the reforms. This protest was the most attended of any disability related protest, and was held across 14 different locations (BBC, 2011) yet was largely ignored by the mainstream media (Butler, 2012). Despite the high attendance, a number of activists were unable to attend due to the effects of their impairments and the inaccessibility of the public transport system. As Ellen Clifford explains,

Disabled people have taken social media and made it into their own medium, where they can have a voice on equal terms with their non-disabled counterparts, something not often afforded by society as a whole...The computer provides a freedom for those with disabilities, it is much easier to protest online than in the centre of London when the Tube is not accessible (quoted in: Ryan, 2014).

This is also emphasised by activist David Gillon:

Many of us wouldn't be able to campaign at all without social media ... I barely get out of the house, and l've given up going into London at all, it's just too exhausting with my pain-based disability. No matter how many marches on parliament are called, I'm physically excluded by the realities of disability, and that's true for so many disabled people. Social media lets me campaign while lying flat on my back if I can't sit up, never mind march on parliament (quoted in: Ryan, 2014).

Social media did not just afford people with disabilities the opportunity to participate in the protest; it garnered mainstream media attention for an important disability issue that had, until it trended on Twitter, been ignored. Sue Marsh, an activist who contributed to the authoring of the Spartacus report explains the significance of social media:

For sick and disabled people campaigning, social media has been revolutionary ... It's been a magic bullet. It's given us political influence, media respect 
and international impact. I can't think of any [other] way sick and disabled people could have done what we and all of the campaign groups together have achieved (quoted in: Ryan, 2014).

The Twitter hashtag \#spartacusreport was able to make use of the affordance offered through the network. Initially it was used by an established network of disability activists to promote and disseminate the report's findings before it was picked up and retweeted by Stephen Fry to his three million followers and then further distributed through political figures Lord Prescott and Alistair Campbell, and then Billy Bragg, Val McDermid and Julie Hesmondhalgh. On the back of this support the hashtag top trended on the network. This lead to the department for work and pensions being drawn into the Twitter conversation itself to put out its justifications on the proposed reforms through using the same hashtag. On the back of the ensuing publicity of this online political action later in the week a number of these proposed reforms were the defeated in the House of Lords (Butler 2012).

More traditional web sites like that of Disabled People Against Cuts, the organisation which coordinated the 2012 Oxford Street protests, also play a complementary role to those physical protests by collating and distributing information that supports the protesters' message. Similarly The Broken of Britain website plays a crucial role as a place for online protest. The site curates social media, bringing together YouTube videos, blogs and Twitter to protest at the consequences of cuts to disability benefits in the United Kingdom (Gentleman, 2011). Kaliya Franklin one of the administrators of the site says she does not see the role of the site as to replace physical protest, but rather to act as a complementary form of protest (quoted in Gentleman, 2011). Another website that has been important is the Black Triangle Campaign's list of 'UK Welfare Reform Deaths':

> Updated tragic list of welfare-related deaths of UK's sick and/or disabled people. This is the tip on the iceberg:

They shall be remembered forevermore. Avenge the dead. Resuscitate the living. We must fight on for freedom from Westminster's murderous policies and support the struggle of all Britain's sick and/or disabled people simultaneously (McArdle, 2014).

As these recent UK disability protests develop, we also see elements of offline and online protest brought together in novel ways. Following the 2012 London Paralympics, a number of disability activists noted the pressure on people with disabilities to be 'superhuman' (Tracey, 2013; White, 2013). Liz Crow, a writer-director working with film, performance, audio and text, was one of those highlighting this issue. Crow argued that there was 
intense pressure 'to be a kind of superhuman when you're in public. And if you're not that, if you're a [benefits] claimant, then you're often cast as a scrounger' (quoted in: Tracey, 2013). Underpinned by a four-year NESTA (National Endowment for Science, Technology and the Arts) fellowship, Crow has explored ways to combine her creative practice and political activism. She comments that despite a long career in disability activism she had two lives - one public and one she kept private:

For about 30 years, I've been aware that I operate in two starkly different modes ... One is public, where I try and come across as energetic and animated and engaged and good at what I do. It's a way of being that's approved of socially. But what people don't see is the other side, where I spend most of my time at home, a great deal of it lying down in my bed. That's in order to prepare for the public thing, and to recover from it. I've always kept that hidden because it feels dangerous to make it public. It feels like l'd be misinterpreted and people won't see me as the whole person that I am (quoted in: Adewunni, 2013).

In protest against welfare benefit overhauls occurring in the United Kingdom, Crowe featured in Bedding Out, a 48-hour long disability performance piece at the Edinburgh Fringe Festival. In Bedding Out-a combination of art, performance and social mediaCrow wanted to show that disability is more complicated than the continuum of superhuman versus scrounger presented by the mainstream media (Macrae, 2012; Tracey, 2013). For disability, and other issues, Crow shows that there is a space in the middle.

Crow describes the performance on her website as a taking her 'private bed-oriented life and placing it in the public arena for all to see over a 48-hour period in order to show that what many see as contradiction, or fraud, is simply the complexity of real life' (Crow, 2012). The performance invites members of the public to join in on 'bedside conversations' which see them 'gathering around the bed to talk about the work, its backdrop and its politics, while those unable to attend in person are invited to take part virtually, through social media' (Crow, 2012).

The show was commissioned to be a part of the Disability Art's Online Perspectives project-the performances in this project were designed to 'spark conversations and debate about the Creative Case for Diversity' (Crow, 2012). By ensuring that those who were unable to attend the installation physically could still participate in the "bedside conversations', social media was integral to the performance. When a version of the performance was staged the previous year, many people contacted Crow to say 'they 
felt represented for the first time, and would like to be there but had their own bed-life. It's a life that's lived in a fair degree of isolation, and social media is breaking down the isolation' (Adewunni, 2013). Indeed the performance given in Salisbury was 'was watched on livestream by more than 9,750 people in over 50 countries' (Crow, 2012).

Emma Tracey, a writer for the BBC disability website Ouch!, discusses the production in terms of Crow's willingness to show her 'most-disabled self', something she had previously kept private as it as 'not socially acceptable' (Tracey, 2013). The Twitter hashtag used for the Salisbury run was active two weeks prior to the show and it began to build a community even before the performances; 'a community of people with bed lives of their own' (Tracey, 2013). The \#BeddingOut hashtag has been taken up as a call to arms-Tweets go beyond the installation piece and address the issues surrounding disability rights in the United Kingdom.

As the work of Liz Crow best exemplifies, in activism, art, and protest in the United Kingdom, spurred on by the welfare reforms, and the spectacular yet troubling event of the Paralympics, we see new possibilities developed for the relationships between disability and technology.

In these technology-inflected United Kingdom disability protests, we see a creative and effective deployment of digital technology, amounting to a new, potent, and far reaching approach to oppressive and unjust policies, practices, and social relations. Harris, Owen and De Ruiter (2012) have observed that '[a]dvocacy and technology are two core strategies used by the disability community to advance the rights of people with disabilities.'

\section{Conclusion}

In this paper, we have presented two typically distinct, but in our view, tightly and tellingly related perspectives on the topic of disability, activism, and technology.

A threshold issue for people with disabilities, especially, when it comes to such digital technology is barriers to access and use. To explore this complex issue, we discussed disability activism concerning technology. This is well-known in a superficial way when it 
comes to web accessibility, but even here there are very significant dynamics at play. Like other kinds of activism, we might point to the contradiction between commercial, 'closed' platforms-whether Facebook, Twitter, or mobile apps-and the kinds of social, cultural, and political innovation they enable, including activism. There is also a peculiar friction between the still dominant framing of disability technology as 'assistive', versus accounts that argue for technology as part of everyday life for all.

From accessibility and technology, we moved to the notable example of the British protests in which the use of technology, especially social media, was key to strategies and tactics, but also the nature of movements that formed. Preston (2011) has noted the role of Facebook and Twitter in people's political participation and particularly their role in popular uprisings, and questions what role these platforms have played in the protests against disability cuts in the United Kingdom. This is an important question, given that Facebook exceeded more than one billion active users worldwide in 2012. The ubiquitous scale of its adoption makes it an ideal place to curate other elements of social media, and to coordinate and communicate protest activities-as we have suggested in our discussion of British disability welfare protests. Yet in other ways, Twitter plays a crucial role. While Twitter has smaller levels of adoption, its embrace by mainstream media, and what Nicola Bruno (2011) has dubbed the 'Twitter effect' on media coverage, also makes it a powerful platform for activism. Twitter's ability to provide dynamic real time information and organise that information through its hashtags and associated metadata also allow it to act as an alternative broadcast mechanism in its own right.

While these social media platforms played a prominent role in disability activism we discuss in this paper, they do so in conjunction with two other elements. Firstly, Facebook and Twitter in these protests were often part of the now typically cross-referenced (and to some extent commercially integrated) ecology of convergent, online, social, mobile, and locative media technologies and applications-including YouTube, Vimeo, Pinterest, Flickr and Instagram. The widespread availability of mobile digital devices such as smart phones and tablets that allow for the rapid dissemination of these platforms to people both involved in protests but also to others in a timely fashion. Secondly, in the ecologies of social media platforms, there is a mixture of more traditional websites, blogs and email mailing lists. While there have been well documented accessibility problems with much of the hardware and software involved (Ellis \& Kent, 2011), these platforms have also proved to be of great benefit for people with disabilities (Hollier, 2012).

In the United Kingdom welfare protests, then, we see disability activists experimenting with uses of digital technologies, and availing themselves of the 'democratic affordances' they offer (Goggin, 2013). Yet the very fact of the use of digital technologies by people with 
disabilities opens up another contradictory area to do with the technologies themselves and the philosophies and values inscribed in, and affiliated with, them.

The fight for equality in disability and work, and the campaign for justice in welfare, tells us much about the oppressive, unfair, and unsustainable ways that labour and value operate, and work, as a result, is defined in our societies. The parallels here with debates on gender and work are very striking; and, of course, there is an obvious and heavy consequential cross-over between disability and other dynamics of gender, race, class, and sexuality, when it comes to work and welfare. A central part of disability rights and activism is to claim technology as par for the (life) course. Citizenship, participation, and potentiality, occurs now through technological enablement; our acts of activism and daily life are shot through with technology.

So the struggle of disability confronting technology, which has largely passed obscured, misrecognised, and marginalised-via the ritual nod to web accessibility-should finally be acknowledged as going to the core of many of the issues about the philosophies, forms, affordances, architectures, and actions predicated on technology in general. In this paper, we have only made a very preliminary contribution to such a project. In particular, much more research and analysis is needed on the specificities of the particular platforms, and the kinds of communication, social practices, and, potentially, new kinds of politics they support. We are only at the very beginning of recognising that disability justice involves a shake-up and reimagining of democracy itself; the same is true of technology too.

\section{Biographical Note}

Katie Ellis is Senior Research Fellow in the Department of Internet Studies at Curtin University. Her books on disability, media and popular culture include Disability and New Media (2011; with Mike Kent), Disability and the Media (2015; with Gerard Goggin), Disability, Ageing and Obesity: Popular Media Identifications (2014; with Debbie Rodan and Pia Lebeck), and Disability and Popular Culture (2015). Dr Ellis is currently undertaking a DECRA funded project on disability and digital televisions.

Gerard Goggin is Professor of Media and Communications, University of Sydney. He is an Australian Research Council Future Fellow, undertaking a project on disability and digital technology. Gerard's books include Routledge Companion to Disability and Media (2017; 
with Katie Ellis and Beth Haller) and Disability and the Media (2015; with Katie Ellis), and with Christopher Newell, Disability in Australia (2005), and Digital Disability (2003).

Mike Kent is a Senior Lecturer in the Department of Internet Studies at Curtin University. His books on disability, media and education include Disability and New Media (2011) with Katie Ellis and An Education in Facebook (2014) with Tama Leaver.

\section{References}

Ackerman, Spencer. 'Occupy the Skies! Protesters Could Use Spy Drones', Wired 17 November (2011), http://www.wired.com/2011/11/ows-drones/

Adam, Alison and Kreps, David. 'Disability and Discourses of Web Accessibility', Information, Communication \& Society 12.7 (2009): 1041-1058.

Adewunni, Bim. 'Artist-Activist Liz Crow's "Bed-Out”: For Disabled Rights', The Guardian, 10 April (2013), http://www.theguardian.com/artanddesign/2013/apr/09/liz-crow-bed-disabledrights

Andrejevic, Mark. iSpy: Surveillance and Power in the Interactive Era (Lawrence, KS: University Press of Kansas, 2007).

Arnardóttir, Oddný Mjöll and Quinn, Gerard (eds). The UN Convention on the Rights of Persons with Disabilities: European and Scandinavian Perspectives (Leiden: Martinus Nijhoff, 2009).

Atos. 'Welfare Reform', (2015), http://uk.atos.net/en-uk/home/your-business/government/ welfare-reform.html

Barnartt, Sharon N. 'Social Movement Diffusion? The Case of Disability Protests in the US and Canada', Disability Studies Quarterly 28.1 (2008), http://dsq-sds.org/article/view/70/70 BBC. 'Disabled People Hold Nationwide Pretests Against Cuts', BBC News, 22 October (2011), http://www.bbc.com/news/uk-15399724

Blanck, Peter. eQuality: The struggle for web accessibility by persons with cognitive disabilities (Cambridge: Cambridge University Press, 2015).

Blume, Stuart. 'What can the Study of Science and Technology tell us about Disability?' in Carol Thomas, Alan Roulstone, and Nick Watson (eds.), Handbook of Disability Studies (New York: Routledge, 2012), 348-359.

Boler, Megan (ed.). Digital Media and Democracy: Tactics in Hard Times. (Cambridge, Mass: MIT Press, 2008).

Brewer, Judy. 'Access to the World Wide Web: Technical and Policy Perspectives', in Wolf- 
gang Preiser and Elaine Ostroff (eds). Universal Design Handbook (New York: McGraw Hill, 2001), 66.1-66.13.

Bruno, Nicola. 'Tweet First, Verify Later? How Real-Time Information is Changing the Coverage of Worldwide Crisis Events.' Reuters Institute Fellowship Paper, University of Oxford (Oxford, Reuters Institute for the Study of Journalism, 2011).

Bruyère, Susanne and Linda Barrington. Employment and Work (Thousand Oaks, CA: Sage, 2012).

Butler, Patrick. 'How the Spartacus Welfare Cuts Campaign Went Viral', The Guardian, 18 January (2012), http://www.theguardian.com/society/2012/jan/17/disability-spartacus-welfare-cuts-campaign-viral

Butler, Patrick. 'Disability Activists use Social Media to put Care Cuts on the Political Agenda', The Guardian, 21 August (2012), http://www.theguardian.com/society/2012/aug/20/ disability-activists-media-care-cuts

Campbell, S. J. et al. Responsible Reform: A Report on the Proposed Changes to Disability Living Allowance. Diary of a Benefit Scrounger, 9 January (2012), https://onedrive.live.com/ view.aspx?resid=CBA86408918CAA9E!132\&cid=cba86408918caa9e\&app=Word\&authkey=! ACOTRaigEZtaJw8

Campbell, S. J. 'I Support the Spartacus Report', Diary of a Benefit Scrounger, 9 January (2012), http://diaryofabenefitscrounger.blogspot.com.au/2012/01/i-support-spartacus-report. html

Chouinard, Vera. 'Body Politics: Disabled Women's Activism in Canada and Beyond', in Ruth Butler \& Hester Parr (eds). Mind and Body Spaces: Geographies of IIIness, Impairment and Disability (New York: Routledge, 1999), 269-294.

Coronel, Sheila S. 'The Media, The Market and Democracy: The Case of the Philippines', Javnost-The Public 8.2 (2001): 109-126.

Crow, Liz. 'Scroungers and Superhumans: Images of Disability from the Summer of 2012: A Visual Enquiry', Journal of Visual Culture 13.2 (2014): 168-181.

Crow, Liz. 'Bedding Out', September (2013), http://www.roaring-girl.com/work/bedding-out/

Dahlgren, Peter. The Political Web: Media, Participation, and Alternative Democracy (Houndsmill, Basingstoke: Palgrave, 2013).

Dean, Jodi. Democracy and Other Neoliberal Fantasies: Communicative Capitalism and Left Politics (Durham, NC: Duke University Press, 2009).

Eide, Arne H. and Ingstad, Benedicte (eds). Disability and Poverty: A Global Challenge (Bristol: Policy Press, 2011).

Ellcessor, Elizabeth. "<ALT=“Textbooks" $>$ : Web Accessibility Myths as Negotiated Industrial Lore', Critical Studies in Media Communication 31.5 (2014): 448-463. 
Ellcessor, Elizabeth. Enabling Access: Media, Disability, and the Politics of Participation, forthcoming.

Ellis, Katie and Gerard Goggin. 'Disability and Social Media' in Jeremy Hunsinger \& Theresa Senft (eds.) Handbook of Social Media (New York: Routledge, 2014).

Ellis, Katie and Gerard Goggin. Disability and the Media (New York: Palgrave Macmillan, 2015).

Ellis, Katie and Mike Kent. 'Community Accessibility: Tweeters Take Responsibility for an Accessible Web 2.0'. Fast Capitalism 6.2 (2010).

Ellis, Katie and Mike Kent. Disability and New Media (New York: Routledge, 2011).

Erevelles, Nirmala. Disability and Difference in Global Contexts: Enabling a Transformative Body Politic (New York: Palgrave, 2011).

Fleisher, Doris and Zames, Frieda. The Disability Rights Movement: From Charity to Confrontation 2 (Philadelphia, PA: Temple University Press, 2011).

Francis, Leslie and Anita Silver. Americans with Disabilities: Exploring Implications of the Law for Individuals and Institutions (New York and London: Routledge, 2000).

Flynn, Eilionóir. From Rhetoric to Action: Implementing the UN Convention on the Rights of Persons with Disabilities (New York: Cambridge University Press, 2011).

Fuchs, Christian. Occupy Media!: The Occupy Movement and Social Media in Crisis Capitalism (Lanham, MD: John Hunt Publishing, 2014a).

Fuchs, Christian. Social Media: A Critical Introduction (London: Sage, 2014b).

Geere, Duncan. 'Sukey Apps Help Protesters avoid Police Kettles', Wired 31 January (2011), http://www.wired.co.uk/news/archive/2011-01/31/sukey-protest-app

Gentleman, Amelia. 'Disability Protesters go on Remote Offensive', The Guardian, 23 March (2011), http://www.theguardian.com/society/2011/mar/23/disability-protests-benefitcuts-remote-offensive

Goggin, Gerard. 'Democratic Affordances: Politics, Media, and Digital Technology after Wikileaks.' Ethical Space 10.2/3 (2013): 6-14.

Goggin, Gerard. 'Communication Rights and Disability Online: Policy and Technology after the World Summit on the Information Society'. Information, Communication \& Society December (2014) http://dx.doi.org/10.1080/1369118X.2014.989879

Goggin, Gerard and Tim Noonan. 'Blogging Disability: The Interface between New Cultural Movements and Internet Technology', in Axel Bruns and Joanne Jacobs (eds). Uses of Blogs (New York: Peter Lang, 2006), 161-172.

Goggin, Gerard and Christopher Newell. Digital Disability: The Social Construction of Disability in New Media (Lanham, MD: Rowman \& Littlefield, 2003). 
Goggin, Gerard and Christopher Newell. 'Editorial Comment: Disability, Identity, and Interdependence: ICTs and New Social Forms', Information, Communication and Society 9.2 (2006): 309-311.

Grech, Shaun and Karen Soldatic (eds). Disability in the Global South: The Critical Handbook (New York: Springer, 2015).

Haller, Beth. Representing Disability in an Ableist World: Essays on Mass Media (Louisville, KY: Avocado Press, 2010).

Harris, Sarah Parker, Randall Owen and Cindy De Ruiter. 'Civic Engagement and People with Disabilities: The Role of Advocacy and Technology', Journal of Community Engagement and Scholarship 5.1 (2012).

Heymann, Jody, Michael Ashley Stein and Gonzalo Moreno (eds). Disability and Equity at Work (Oxford: Oxford University Press, 2014).

Hickey-Moody, Anna and Denise Wood. 'Virtually Sustainable: Deleuze \& Desiring Differenciation in Second Life', Continuum 22 (2008): 805-816.

Hollier, Scott. Sociability: Social Media for People with a Disability (Sydney: Media Access, 2012), https://accan.org.au/our-work/research/444-sociability-social-media-for-people-witha-disability

Hughes, Bill. 'Disability Activisms: Social Model Stalwarts and Biological Citizens', Disability \& Society 24.6 (2009): 677-688.

Imrie, Rob and Rachel Luck. 'Designing Inclusive Environments: Rehabilitating the Body and the Relevance of Universal Design', Disability and Rehabilitation 36.16**(2014): 1315-1319.

Ismail, Sarah. 'Why No Mention of Kettling Disabled Protesters', The Guardian, 31 January (2011), http://www.theguardian.com/society/joepublic/2011/jan/31/kettling-disabled-protesters-welfare-reform

Kelly, Christine. 'Towards Renewed Descriptions of Canadian Disability Movements: Disability Activism outside of the Non-Profit Sector', Canadian Journal of Disability Studies 2.1 (2013), http://dx.doi.org/10.15353/cjds.v2i1.68

Krieger, Linda Hamilton. Backlash Against the ADA: Reinterpreting Disability Rights (Ann Arbor, MI: University of Michigan, 2003).

Kulick, Don and Jens Rydström. Loneliness and Its Opposite: Sex, Disability, and the Ethics of Engagement (Durham, NC: Duke University Press, 2015).

Lewthwaite, Sarah. 'Web Accessibility Standards and Disability: Developing Critical Perspectives on Accessibility.' Disability and Rehabilitation 36.16 (2014): 1375-1383.

Lievrouw, Leah A. Alternative and Activist New Media. (Cambridge: Polity, 2011).

Lindsay, Colin and Donald Houston (eds). Disability Benefits, Welfare Reform and Employment Policy (New York: Palgrave Macmillan, 2013). 
Macrae, Ian. 'Why Liz Crow is Bedding Out', Disability Now May (2013), http://www.disabilitynow.org.uk/article/why-liz-crow-bedding-out

Marin, Bernd, Christopher Prinz and Queisser, Monika (eds). Transforming Disability Welfare Policies: Towards Work and Equal Opportunities (Aldershot, UK: Ashgate, 2004).

McArdle, John. 'UK Welfare Reform Deaths-Updated List'. Black Triangle Campaign, 21 October (2014), http://blacktrianglecampaign.org/2014/10/21/uk-welfare-reform-deaths-updated-list-october-21st-2014/

Meikle, Graham. Future Active: Media Activism and the Internet (Sydney: Pluto Press; London: Routledge, 2012).

Mills, Mara. 'Deafening: Noise and the Engineering of Communication in the Telephone System', Grey Room 43 (2011): 118-143.

Morse, Felicity. 'Scuffles At Atos Paralympics Protest As Police and Disability Campaigners Clash', The Huffington Post (UK) 31 August (2012), * http://www.huffingtonpost. co.uk/2012/08/31/atos-paralympics-protest-uk-uncut-disability-_n_1846633.html

Morton, Rick and Rachel Baxendale. 'ABC Kicks Out Website Protest', The Australian, 1 July (2014), http://www.theaustralian.com.au/media/abc-kicks-out-website-protest/storye6frg996-1226972886005

Moser, Ingunn. 'On Becoming Disabled and Articulating Alternatives: The Multiple Modes of Ordering Disability and their Interferences', Cultural Studies 19 (2005): 667-700.

McRuer, Robert. Crip Theory: Cultural Signs of Queerness and Disability (New York: New York University Press, 2006).

Newell, Christopher. 'The Disability Rights Movement in Australia: A Note from the Trenches’, Disability \& Society 11.3 (2006): 429-432.

Oliver, Mike, and Colin Barnes. The New Politics of Disablement. (Houndsmills, UK: Palgrave, 2012).

Padovani, Claudia and Andrew Calabrese (eds). Communication Rights and Social Justice: Historical Accounts of Transnational Mobilizations (Basingstoke, UK: Palgrave Macmillan, 2014).

Peck, Sunil. 'Direct action! Life on the streets', Disability Now, November (2010), http:// www.disabilitynow.org.uk/article/direct-action-life-streets

Pelka, Fred. What Have We Done: An Oral History of the Disability Rights Movement. (Amherst, MA: University of Massachusetts Press, 2012).

Pertierra, Raul, Eduardo F. Ugarte, Alicia Pingol, Joel Hernandez, and Nikos L.Dacanay. Txt-ing Selves: Cellphones and Philippine Modernity. (Manila: De La Salle University Press, 2002).

Preiser, Wolfgang F. E. and Elaine Ostroff (eds). Universal Design Handbook. (New York: McGraw-Hill, 2001). 
Preston, Claire. 'Resisting Disability Benefits Cuts in a Digital Age', paper presented at the Social Policy Association Conference. University of Lincoln, 4-6 July (2011), http://www. social-policy.org.uk/lincoln2011/Preston\%20P6.pdf

Ratto, Matt, and Megan Boler (eds). DIY Citizenship: Critical Making and New Media. (Cambridge, MA: MIT Press, 2014).

Roulstone, Alan. Enabling Technology: Disabled People, Work, and New Technology (Buckingham, UK, and Philadelphia, PA: Open University Press, 1998).

Roulstone, Alan. Understanding Disability Policy (Bristol: Policy Press, 2012).

Ryan, Frances. 'Social Media Means the Voices of the Disabled Can no Longer be Ignored by Those in Power, New Statesman, 7 August (2014), http://www.newstatesman. com/2014/07/social-media-means-voices-disabled-can-no-longer-be-ignored-those-power

Samuels, Ellen. Fantasies of Identification: Disability, Gender, Race. (New York: New York University Press, 2014).

Sandell, Richard, Jocelyn Dodd and Rosemarie Garland-Thomson (eds). Re-Presenting Disability: Activism and Agency in the Museum (London and New York: Routledge, 2010).

Schuler, Douglas and Aki Namioka (eds). Participatory Design: Principles and Practices (Hillsdale, NJ: Erlbaum Associates, 1993).

Scotch, Richard. 'Disability as the Basis for a Social Movement: Advocacy and the Politics of Definition', Journal of Social Issues 44.1 (1988): 159 - 72.

Shakespeare, Tom. 'Disabled People's Self-Organisation: A New Social Movement?', Disability, Handicap and Society, 8.3 (1993): 249-264.

Shakespeare, Tom, ed. Disability Research Today: International Perspectives (London and New York: Routledge, 2015).

Shapiro, Joseph. No Pity: People with Disabilities forging a New Civil Rights Movement (New York: New York Times Books, 1993).

Shildrick, Magrit. Dangerous Discourses of Disability, Subjectivity, and Sexuality. (Basingstoke, UK: Macmillan, 2009).

Snyder, Sharon, and David T. Mitchell 'Re-engaging the Body: Disability Studies and the Resistance to Embodiment', Public Culture, 13.3 (2001): 367-389.*

Soldatic, Karen and Helen Meekosha. The Global Politics of Impairment and Disability: Processes and Embodiments (London: Routledge, 2014).

Soldatic, Karen, Hannah Morgan and Alan Roulstone (eds). Disability, Spaces and Places of Policy Exclusion (London and New York: Routledge, 2014).

Soldatic, Karen, Kim Spurway and Helen Meekosha. 'Hard Yakka': Living with a Disability in the West Kimberley (Sydney: University of New South Wales, 2014), http://www.daa.wa.gov. 
au/Documents/ReportsPublications/Staff\%20Documents/Whats\%20on\%20Today/Hard_Yakka_July_2014_Soldatic-Spurway-Meekosha-libre.pdf

Sourbati, Maria. 'Disabling Communications? A Capabilities Perspective on Media Access, Social Inclusion, and Communication Policy', Media, Culture \& Society 34.5 (2012): 571-587.

Taylor, Matthew. 'Students Protests Video allegedly shows Police Pulling Man out of Wheelchair', The Guardian, 14 December (2010), http://www.theguardian.com/uk/2010/dec/14/ student-protests-video-protester-wheelchair

Thomas, Nicholas. Entangled Objects: Exchange, Material Culture, and Colonialism in the Pacific (Cambridge, MA: Harvard University Press, 1991).

Titchkovsky, Tanya. The Question of Access: Disability, Space, Meaning (Toronto: University of Toronto Press, 2011).

Tracey, Emma. 'Artist Goes to Bed in Public to Raise Disability Awareness', (2013), http:// www.bbc.co.uk/blogs/legacy/ouch/2013/03/artist_goes_to_bed_in_public_t.html Trevisan, Filippo. 'Disabled People, Digital Campaigns, and Contentious Politics: Upload Successful or Connection Failed?', in Richard Scullion, Roman Gerodimos, Danile Jackson and Darren Lilleker (eds). The Media, Political Participation, and Empowerment (London: Routledge, 2013), 175-191.

Trevisan, Filippo. Disability Rights Advocacy and New Media in Britain and America (London: Routledge, 2015).

Trevisan, Filippo. 'Scottish Disability Organizations and New Media: A Path to Empowerment or 'Business as Usual'?', Disability Studies Quarterly 34.3 (2014), http://dsq-sds.org/ article/view/3359/3648

Tsing, Anna Lowenhaupt. Friction: An Ethnography of Global Connection (Princeton, NJ: Princeton University Press, 2005).

Twitter. 'Improving accessibility of Twitter.com' December 2014 (2013) from https://blog. Twitter.com/2013/improving-accessibility-of-Twittercom

Twitter. 'Twittera11y team', (2014) https://Twitter.com/a11yteam

Waddington, Lisa, Gerard Quinn and Eilionóir Flynn (eds). European Yearbook of Disability Law 5 (Cambridge, UK: Intersentia, 2015).

White, Peter. 'The Triumph of Hope over Reality', (2013), http://disabilitynow.org.uk/article/ triumph-hope-over-reality

Youmans, William Lafi and Jillian C. York 'Social Media and the Activist Toolkit: User Agreements, Corporate Interests, and the Information Infrastructure of Modern Social Movements', Journal of Communication, 62.2 (2012): 315-329. 
The LOCKSS System has the permission to collect, preserve and serve this open access Archival Unit

This Isuue of the Fibreculture Journal by The Fibreculture Journal Incorporated is licensed under a Creative Commons Attribution 4.0 International License.

\section{OPEN HUMANITIES PRESS}

The Fibreculture Journal is published by The Fibreculture Journal Incorporated in partnership with Open Humanities Press. 